\title{
Synthesis, characterization and properties of a copper complex with dicyano acetic acid methyl ester ligand derived from tetracyanoethylene
}

Chen-Neng Lin, Ling-Zhi Tang, Shi-Tao Ren, Li-Ping Ye, Cai-Hong Chen*, Shu-Zhong Zhan*

College of Chemistry \& Chemical Engineering, South China University of Technology, Guangzhou 510640, China

\begin{abstract}
The reaction of $\mathrm{CuCl}$ with tetracyanoethylene (TCNE) affords a copper(II) complex, $\left[(\text { DCAE })_{2} \mathrm{Cu}\left(\mathrm{H}_{2} \mathrm{O}\right)_{2}\right] 1$ (DCAE: dicyano-acetic acid methyl ester, derived from TCNE). Its structure has been characterized by physics-chemical and spectroscopic methods. Magnetic studies exhibit that no magnetic coupling between two $\mathrm{Cu}^{2+}$ via DCAE $^{-}$unit in the temperature range 300-9 K. Electrochemical studies show that this copper complex can act as an electrocatalyst for hydrogen generation both from acetic acid, with a turnover frequency (TOF) of 74 moles of $\mathrm{H}_{2}$ per mole of catalyst per hour an potential (OP) of 941.6 (in $\mathrm{CH}_{3} \mathrm{CN}$ ), and from aqueous buffer ( $\mathrm{pH} 7.0$ ) with a TOF of 285 moles of $\mathrm{H}_{2}$ per mole of catalyst per hour at an OP of $787.6 \mathrm{mV}$.

Keywords: TCNE; copper complex; molecular catalyst; proton or water reduction; $\mathrm{H}_{2}$ evolution
\end{abstract}

\footnotetext{
* Corresponding author. Fax: +86-20-87112053.

E-mail address: shzhzhan@scut.edu.cn (S.-Z. Zhan).
} 


\section{Introduction}

We are interested in the chemistry of tetracyanoethylene (TCNE), because of its versatile reactions in different directions [1-5]. Additionally, TCNE can be employed as linkers to bridge metal centers, giving rise to oligonuclear complexes and coordination polymers. Typically, the strong electron-acceptor capacity of TCNE, coupled with its ability to serve as a ligand through two or more of its $\mathrm{CN}$ groups, can allow the preparation of polymeric materials [6-9]. So far, several molecular magnetic materials have been provided by reactions of TCNE with paramagnetic metal ions [10-14]. Despite these advances, few materials based on copper complexes supported by TCNE are known. With the goal of giving new organic-based magnets, and molecular-based materials, that stand a good chance of displaying interesting electronic properties, we tried the reaction of $\mathrm{CuCl}$ and $\mathrm{TCNE}$ with a molar ratio set of 1:2. Surprisingly, an unexpected copper complex, [(DCAE $\left.)_{2} \mathrm{Cu}\left(\mathrm{H}_{2} \mathrm{O}\right)_{2}\right] \mathbf{1}$ was obtained. In this paper, we describe the synthesis, structure and properties of this complex, as well as its electrocatalytic hydrogen generation both from acetic acid and aqueous buffer.

\section{Experimental section}

\subsection{Physical measurements}

Sodium dicyano-acetic acid methyl ester, NaDCAE was prepared following the literature procedures [15]. Elemental analyses for $\mathrm{C}, \mathrm{H}$, and $\mathrm{N}$ were obtained on a Perkin-Elmer analyzer model 240 instrument. UV-Vis spectra were measured on a 
Hitachi U-3010 spectrometer. ESI-MS experiment was performed on a Bruker Daltonics Esquire 3000 spectrometer by introducing samples directly into the ESI source using a syringe pump. Magnetic susceptibility data for powder sample were collected in the temperature range 2-300 $\mathrm{K}$ with a Quantum Design SQUID Magnetometer MPMS XL-7. Effective magnetic moments were calculated by the equation $\mu_{\text {eff }}=2.828\left(\chi_{M} \mathrm{~T}\right)^{1 / 2}$, where $\chi_{M}$ is the molar magnetic susceptibility. Cyclic voltammograms (CVs) were measured on a CHI-660E electrochemical analyzer under $\mathrm{N}_{2}$ using a three-electrode cell in which a glassy carbon electrode (1 $\mathrm{mm}$ in diameter) was the working electrode, a saturated $\mathrm{Ag} / \mathrm{AgNO}_{3}(1.0 \mathrm{M})$ or $\mathrm{Ag} / \mathrm{AgCl}$ electrode was the reference electrode, and a platinum wire was the auxiliary electrode. In organic media, the ferrocenium/ferrocene couple was used as an internal standard, and $0.10 \mathrm{M}$ $\left[(\mathrm{n}-\mathrm{Bu})_{4} \mathrm{~N}\right] \mathrm{ClO}_{4}$ was used as the supporting electrolyte. Controlled-potential electrolysis (CPE) in aqueous media was conducted using an air-tight glass double compartment cell separated by a glass frit. The working compartment was fitted with a glassy carbon plate and an $\mathrm{Ag} / \mathrm{AgCl}$ reference electrode. The auxiliary compartment was fitted with a Pt gauze electrode. The working compartment contained a $50 \mathrm{~mL}$ of 0.25 M phosphate buffer solution, while the auxiliary compartment was filled with 35 mL phosphate buffer solution. After addition of complex 1, CVs were recorded. After electrolysis, a $0.50 \mathrm{~mL}$ aliquot of the headspace was removed and replaced with 0.50 $\mathrm{mL}$ of $\mathrm{CH}_{4}$. The headspace sample was injected into the gas chromatograph (GC). 


\subsection{Synthesis of complex 1}

A solution of TCNE $(0.261 \mathrm{~g}, 2 \mathrm{mmol})$ in methanol $(10 \mathrm{~mL})$ was treated with a solution of $\mathrm{CuCl}(0.100 \mathrm{~g}, 1 \mathrm{mmol})$ in $\mathrm{CH}_{3} \mathrm{CN} /$ methanol $(5 \mathrm{~mL})$. The mixture was stirred at room temperature for $1 \mathrm{~h}$, no reaction was observed. After the addition of one drop of water, the solution color turned from yellow to green. Green crystals were obtained from the filtrate which was allowed to stand at room temperature for several days, collected by filtration, and dried in vacuo. Yield: $0.193 \mathrm{~g}(56.0 \%)$. Calcd for $\mathrm{C}_{10} \mathrm{H}_{14} \mathrm{CuN}_{4} \mathrm{O}_{8}$ : C 31.46, H 2.64, N 14.68. Found: C 31.62, H 2.68, N 14.6. IR bands $\left(\mathrm{KBr}\right.$ pellets, $\left.\mathrm{cm}^{-1}\right): v=2251(\mathrm{~m}), 2182(\mathrm{~s})(\mathrm{v}(\mathbf{C} \equiv \mathbf{N})) ; v=1641(\mathrm{~s})\left(v\left(-\mathrm{CO}_{2}^{-}\right)\right)$.

\subsection{Crystal structure determination}

X-ray data measurement for complex 1 was conducted on a Bruker Smart Apex II

DUO area detector using graphite monochromated Mo-K $\alpha$ radiation $(\lambda=0.71073 \AA)$. All empirical absorption corrections were applied by using the SADABS program [16]. The structure was solved using direct methods and the corresponding non-hydrogen atoms are refined anisotropically. All the hydrogen atoms of the ligands were placed in calculated positions with fixed isotropic thermal parameters and included in the structure factor calculations in the final stage of full-matrix least-squares refinement. All calculations were performed using the SHELXTL-97 computer program [17]. Crystallographic data for complex $\mathbf{1}$ are given in Table S1 and selected bond lengths and angles are listed in Table S2. CCDC 671102 contains the supplementary crystallographic data for this paper. This data can be obtained free 
of charge via http://www.ccdc.cam.ac.uk/conts/retrieving.html.

\section{Results and discussion}

\subsection{General characterization}

In order to prepare metal-organic frame linked by TCNE, we tried the reaction of $\mathrm{CuCl}$ and TCNE at a molar ratio set of 1:2. However, this reaction affords a water soluble copper(II) complex 1 supported by two dicyano- acetic acid methyl ester (DCAE) ligands (Scheme 1). Based on the literature precedent $[2,15,18]$, a possible mechanism for the formation of $\mathrm{DCAE}^{-}$from TCNE was illustrated by Scheme 2. First, the addition of $\mathrm{CuCl}$ leads to the formation of $[\mathrm{TCNE}]^{-}$, then provides an intermediate $\left[\mathrm{C}_{2}(\mathrm{CN})_{3}\right]^{\circ}$ by losing one $\mathrm{CN}^{-}$. In the presence of $\mathrm{O}_{2}$, further reaction provides one dicyano species $\left[(\mathrm{CN})_{2} \mathrm{C}=\mathrm{C}-\mathrm{O}\right]^{-}$by losing one $\mathrm{CN}^{-}$. Finally, the reaction of $\left[(\mathrm{CN})_{2} \mathrm{C}=\mathrm{C}-\mathrm{O}\right]^{--}$with methanol (solvent) provides $\mathrm{DCAE}^{-}$anion. This result shows that TCNE undergoes numerous reactions [19]. From Fig. S1 (infrared spectrum of 1), complex 1 shows two $v(\mathrm{C} \equiv \mathrm{N})$ stretches at 2251 and $2182 \mathrm{~cm}^{-1}$ at lower energy than that of the free tetracyanoethylene (2258 and $2215 \mathrm{~cm}^{-1}$ ) (Fig. S2), assigning to the cyanide mode of $\mathbf{1}$. As shown in Fig. S3, complex 1 exhibits an absorption band at about $228 \mathrm{~nm}$, which can be assigned to metal-ligand charge transitions. From Fig. S4, in the $\mathrm{pH}$ range 2.5 to 11.0 , no new peak appeared, suggesting this complex is stable under these conditions. 


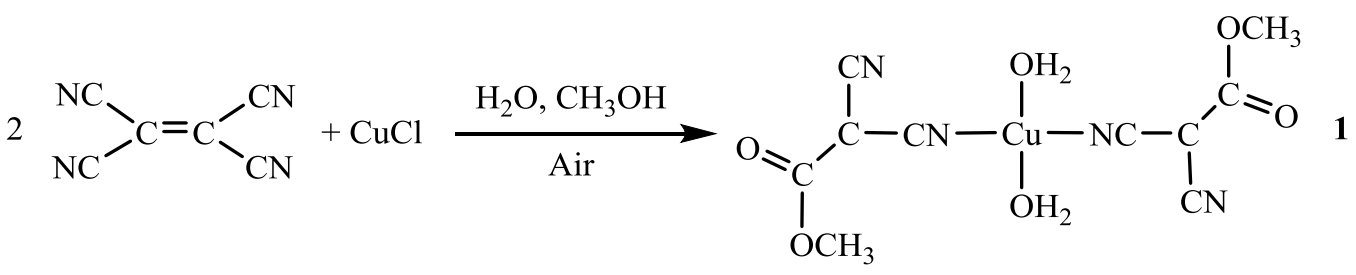

Scheme 1 Synthesis of complex 1.

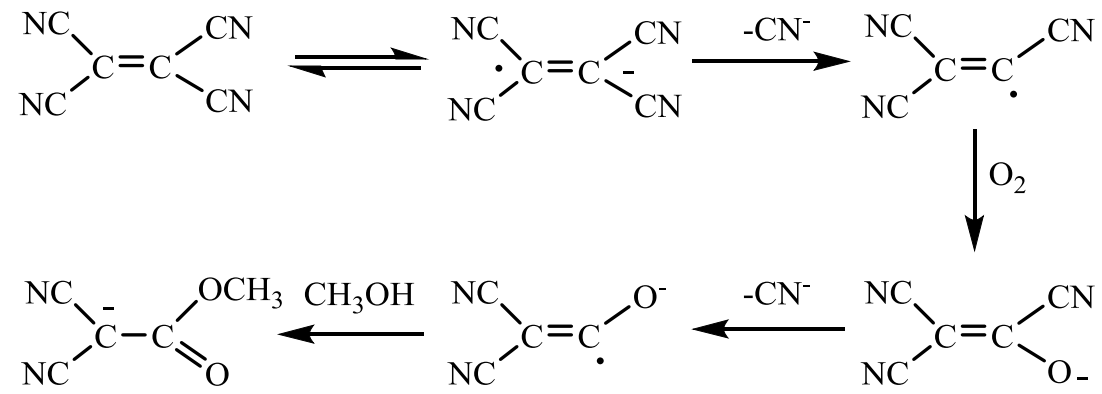

Scheme 2 The procedure for the formation of dicyano- acetic acid methyl ester anion (DCAE').

Complex 1 crystallizes in space group P2(1)/n, with two formula units present per unit cell. As shown in Fig. 1, 1 consists of one $\mathrm{Cu}^{2+}$, two $\mathrm{H}_{2} \mathrm{O}$ and two dicyano-acetic acid ester anions. The coordination geometry of copper in $\mathbf{1}$ is tetragonal, and is coordinated by two $\mathrm{O}$ atoms from $\mathrm{H}_{2} \mathrm{O}$, two $\mathrm{N}$ atoms from dicyano-acetic acid ester anion. $\mathrm{Cu}-\mathrm{N}$ distances are $1.9617(15)$, and $1.9618(15) \AA$, respectively, and the $\mathrm{Cu}-\mathrm{O}$ lengths are 1.9631(13), and 1.9632(13) A, respectively. Interestingly, the introduction of methanol into complex 1 led to the dissociation of a $\mathrm{DCAE}^{-}$ion from copper atom. This was in agreement with result from ESI-MS measurement which exhibited one ion at a mass-to-charge ratio $(\mathrm{m} / \mathrm{z})$ of 286.0946 , with the mass and isotope distribution pattern corresponding to that of $\left[(\mathrm{DCAE}) \mathrm{Cu}\left(\mathrm{H}_{2} \mathrm{O}\right)_{2}\left(\mathrm{CH}_{3} \mathrm{OH}\right)_{2}\right]^{+}$(Fig. S5).

\subsection{Magnetic properties}


The magnetic behavior of complex 1 was investigated in the temperature range 2-300 $\mathrm{K}$ for molar susceptibility. As shown in Fig. 2a, the value of $\chi_{M} \mathrm{~T}$ at room temperature, $0.499 \mathrm{~cm}^{3} \mathrm{Kmol}^{-1}$, is close to the value of $0.50 \mathrm{~cm}^{3} \mathrm{Kmol}^{-1}$ of one copper(II) ions ( $\mathrm{S}=$ 1/2). This value remain almost constant with cooling down up to $9.0 \mathrm{~K}$, then they decrease sharply at low temperature reaching a value of $0.25 \mathrm{~cm}^{3} \mathrm{Kmol}^{-1}$ at $2.0 \mathrm{~K}$. The decrease of $\chi_{M} \mathrm{~T}$ values in the low temperature region may be due to very weak antiferromagnetic coupling between metal ions. This weak antiferromagnetic interaction can be understood taking into account the large separation (about $5.5 \AA$ ) between the paramagnetic copper centres in complex $\mathbf{1}$. This result is in agreement with the magnetic analysis by Curie-Weiss law $\left(\chi_{M}=\mathrm{C} /(\mathrm{T}-\theta), \theta=-0.95^{\circ}\right)($ Fig. $2 \mathrm{~b})$. Based on above analysis, the oxidation state of copper in complex $\mathbf{1}$ is +2 .

\subsection{Linear scan voltammetry}

It has been shown that copper complexes can act as electro-catalysts for hydrogen production via an unstable hydride intermediate [20,21]. To study its function as one new material, e. g. electrocatalyst in liquid, first we investigated the electrochemical behavior via using linear scan voltammetry (LSV).

As shown in Fig. 3, the potentials for reduction of $\mathbf{1}$ are the same as that of the back-ground (ca. $-1.70 \mathrm{~V}$ versus $\mathrm{Ag} / \mathrm{AgCl}$ ), indicating that no proton is lost during the initial reduction. According to Fig. 3, the peak current increases continually with increasing concentrations of complex 1 from 0.0 to $0.156 \mathrm{mM}$, and no turning point is found, demonstrating that $\mathbf{1}$ undergoes redox cycling during the electrochemical 
experiments. From Fig. S6, the catalytic current increases significantly with decrease of $\mathrm{pH}$ from 8.0 to 4.3 , suggesting that there is a protonation step in the catalytic reaction.

\subsection{Cyclic voltammetry}

We then explored its electrochemical properties via cyclic voltammetry, which was conducted in $\mathrm{CH}_{3} \mathrm{CN}$ with $0.10 \mathrm{M}\left[(\mathrm{n}-\mathrm{Bu})_{4} \mathrm{~N}\right] \mathrm{ClO}_{4}$ as the supporting electrolyte. As shown in Fig. 4a, the cyclic voltammogram of $2.67 \mathrm{mM}$ complex 1 shows a quasireversible couple at $0.69 \mathrm{~V}$ and a reversible redox couple at $1.11 \mathrm{~V}$ versus $\mathrm{Ag} / \mathrm{AgNO}_{3}$, respectively. For comparison, NaDCAE displays a quasireversible rodox peak at $0.67 \mathrm{~V}$ and a reversible redox couple at $1.12 \mathrm{~V}$ versus $\mathrm{Ag} / \mathrm{AgNO}_{3}$ (Fig. S7). These two oxidation waves of $\mathbf{1}$, being close to the oxidations of NaDCAE, are assigned to NaDCAE. Scanning to cathodic potential reveals two quasireversible couples at $-0.82 \mathrm{~V}$ and $-1.50 \mathrm{~V}$ versus $\mathrm{Ag} / \mathrm{AgNO}_{3}$, which are assigned to the $\mathrm{Cu}{ }^{\mathrm{I} / \mathrm{I}}$ and $\mathrm{Cu}^{\mathrm{I} / 0}$ couples, respectively. Scan rate analyses of voltammograms exhibit linear dependences in plots of current versus $v^{1 / 2}$ (Fig. S8), as expected for diffusional species at all observed redox events.

\subsection{Electrocatalytic hydrogen generation from acetic acid in $\mathrm{CH}_{3} \mathrm{CN}$}

To determine catalytic activity of this copper complex, acetic acid was chosen as proton resource. From Fig. $4 \mathrm{~b}$ it can be seen that the catalytic current near -1.55 and $-0.94 \mathrm{~V}$ versus $\mathrm{Ag} / \mathrm{AgNO}_{3}$ increased markedly with the sequential increments of acetic acid concentration (from 0.00 to $5.964 \mathrm{mM}$ ). This rise in current can be 
assigned to the catalytic generation of $\mathrm{H}_{2}$ from acetic acid [22]. The result indicates that $\mathrm{H}_{2}$ production electrocatalyzed by complex 1 requires the reduction potentials of $\mathrm{Cu}(\mathrm{II})$ to $\mathrm{Cu}(\mathrm{I})$ and $\mathrm{Cu}(\mathrm{I})$ to $\mathrm{Cu}(0)$. Note, with the acetic acid concentration increased from 0.0 to $1.36 \mathrm{mM}$ (Fig. 4b), the reduction potentials near -1.55 and $-0.94 \mathrm{~V}$ versus $\mathrm{Ag} / \mathrm{AgNO}_{3}$ moved to more anodic value for $460 \mathrm{mV}$ from -1.55 to $-1.09 \mathrm{~V}$ versus $\mathrm{Ag} / \mathrm{AgNO}_{3}$ and for $110 \mathrm{mV}$ from -0.94 to $0.83 \mathrm{~V}$ versus $\mathrm{Ag} / \mathrm{AgNO}_{3}$, respectively. Upon the addition of $5.964 \mathrm{mM}$ acetic acid, the onset of catalytic current moved positive for about $300 \mathrm{mV}$ from -0.74 to $0.44 \mathrm{~V}$ versus $\mathrm{Ag} / \mathrm{AgNO}_{3}$. On the basis of literature precedents [23] and above analyses, the catalytic cycle depicted in Scheme 3 for the generation of hydrogen from acetic acid mediated by $\mathbf{1}$ was proposed. One-electron reduction of $\left[(\mathrm{DCAE}) \mathrm{Cu}^{\mathrm{II}}\left(\mathrm{H}_{2} \mathrm{O}\right)_{2}\right]^{+}$gives a putative [(DCAE) $\mathrm{Cu}^{\mathrm{II}}\left(\mathrm{H}_{2} \mathrm{O}\right)_{2}$ ] species. Addition of $\mathrm{H}^{+}$to $\left[(\mathrm{DCAE}) \mathrm{Cu}^{\mathrm{II}}\left(\mathrm{H}_{2} \mathrm{O}\right)_{2}\right]$ affords the $\mathrm{Cu}^{\mathrm{III}}-\mathrm{H}$ species. Further one-electron reduction of the $\mathrm{Cu}^{\mathrm{III}}-\mathrm{H}$ species affords dihydrogen, and regenerates the starting complex 1. Further mechanistic studies are under investigation. 
<smiles></smiles><smiles>COC(=O)ONC1C=CC1CCOC(C)=O</smiles><smiles>CCCCCCCC(C)CC(C)C</smiles><smiles>CCC(O)C(C#N)C(C#N)C(=O)OC</smiles><smiles>COC(=O)C(C#N)C(O)O</smiles><smiles>CCCCCCC</smiles><smiles>COC(=O)C(C#N)N=C(O)C(O)[18F]</smiles>

Scheme 3 The possible catalytic mechanism for proton reduction by complex $\mathbf{1}$.

To verify that complex $\mathbf{1}$ is responsible for the catalysis indeed, several control experiments were carried out. Under the same conditions, CVs of NaDCAE, acetic acid, $\mathrm{CuCl}$, and the mixture of $\mathrm{NaDCAE}$ and $\mathrm{CuCl}$ were each measured. As can be seen in Fig. S7 and Figs. S9-S11, the catalytic performance achieved by $\mathbf{1}$ is not matched by just $\mathrm{NaDCAE}$, acetic acid and $\mathrm{CuCl}$, as might arise from dissociation of NaDCAE, nor can it be accomplished with $\mathrm{DCAE}^{-}$bound to copper center. Therefore, a coordination of the copper ion and $\mathrm{DCAE}^{-}$is essential for catalytic activity. 
The system was further characterized by bulk electrolysis from $0.13 \mu \mathrm{M}$ complex 1 in $\mathrm{CH}_{3} \mathrm{CN}$ with acetic acid at variable applied potential. From Fig. S12a (the total charges of bulk electrolysis from complex $\mathbf{1}$ in the presence of acetic acid), the charge significantly increased at lower potential. When the applied potential was $-1.45 \mathrm{~V}$ versus $\mathrm{Ag} / \mathrm{AgNO}_{3}$, the maximum charge reached $154 \mathrm{mC}$ used $2 \mathrm{~min}$. Whilst a controlled-potential electrolysis (CPE) experiment under the same potential but without complex 1 gave a charge of only $16 \mathrm{mC}$ (Fig. S12b), indicating that this complex does indeed serve as effective hydrogen producer under such conditions. According to Equations (1) [24] and (2) [25], the TOF was estimated to be 74 moles of hydrogen per mole of catalyst per hour at an overpotential of $941.6 \mathrm{mV}$ (Fig. S13).

$\mathrm{TOF}=\Delta C /\left(\mathrm{F}^{*} n_{1} * n_{2} * t\right)$

Overpotential $=$ Applied potential $-\mathrm{E}^{\odot} \mathrm{HA}$

$$
=\text { Applied potential }-\left(\mathrm{E}^{\odot}{ }_{\mathrm{H}}{ }^{+}-(2.303 R T / F) \mathrm{p} K_{a \mathrm{HA}}\right)
$$

Where, $\Delta C$ is the charge from the catalyst solution during CPE minus the charge from solution without catalyst during CPE; $\mathrm{F}$ is Faraday's constant, $n_{1}$ is the number of moles of electrons required to generate one mole of $\mathrm{H}_{2}, n_{2}$ is the number of moles of catalyst in solution, and $\mathrm{t}$ is the duration of electrolysis.

\subsection{Electrocatalytic hydrogen evolution from aqueous buffer}

We then explored the electrocatalytic behavior in aqueous media. As shown in Fig. S14, the current strength increased with increasing concentrations of complex 1 from 0.00 to $30.43 \mathrm{mM}$. To further probe the nature of this reduction process, we 
investigated the $\mathrm{pH}$ dependence of the cathodic peak potential. From Fig. S15, the current strength increased significantly under lower $\mathrm{pH}$ values, which is consist with a catalytic process [26], indicating $\mathbf{1}$ also can catalyze water reduction to $\mathrm{H}_{2}$.

To further get the evidence for the activity in aqueous media, the bulk electrolysis of a $7.14 \mu \mathrm{M}$ complex 1 was conducted in a neutral buffer under variable applied potentials. When the applied potential was $-1.45 \mathrm{~V}$ versus $\mathrm{Ag} / \mathrm{AgCl}$, the maximum charge was $95 \mathrm{mC}$ over $2 \mathrm{~min}$ without complex 1 (Fig. 5a). Under the same conditions, the charge reached $748 \mathrm{mC}$ with addition of complex 1 (Fig. 5b), accompanied by the appearance of gas bubbles which was confirmed to be $\mathrm{H}_{2}$ by GC analysis. From Fig. S16, 9.24 mL of $\mathrm{H}_{2}$ was obtained over an electrolysis period of 2 $\mathrm{h}$ with a Faradaic efficiency of $95 \%$ for dihydrogen (Fig. S17). According to Equations (1) and (3) [27], we also calculated the TOF for the catalyst as reaching a maximum of 285 moles of hydrogen per mole of catalyst per hour at an OP of 787.6 $\mathrm{mV}$ (Fig. S18).

Overpotential $=$ Applied potential $-\mathrm{E}(\mathrm{pH})=$ Applied potential $-(-0.059 \mathrm{pH})$

It is not easy to compare the catalytic efficiency between different electrocatalytic systems in term of TOF, due to possible differences in the experimental conditions conducted. Based on TOF, the electro-catalytic activity of complex $\mathbf{1}$ is higher than a copper complex supported by a tetradentate amine phenol ligand that shows a TOF of $104.3 \mathrm{~mol}$ of $\mathrm{H}_{2}$ per mole of catalyst per hour at an OP of $839 \mathrm{mV}$ [28], but lower than $\mathrm{Cu}($ oxpn $) \mathrm{Cu}(\mathrm{OH})_{2}$ [oxpn $=N, N^{\prime}$-bis(3-aminopropyl)oxamido] that exhibits a TOF of $1383 \mathrm{~mol}$ of hydrogen per mole of catalyst per hour at an OP of $689 \mathrm{mV}$ [29]. 


\subsection{Investigation of the stability and durability of complex 1}

In order to determine whether 1 retains activity over longer time periods, a $72 \mathrm{~h} \mathrm{CPE}$ at $-1.45 \mathrm{~V}$ versus $\mathrm{Ag} / \mathrm{AgCl}$ was conducted in a neutral buffer containing $10.56 \mu \mathrm{M}$ complex 1. According to Fig. S19, the catalyst affords a charge build-up over time, with no substantial loss in activity used 48 hours, and a total of $739 \mathrm{C}$ is passed during the electrolysis.

\section{Conclusion}

In this paper, we have described the reactivity of TCNE with $\mathrm{CuCl}$. In the presence of methanol, TCNE affords a dicyano- acetic acid methyl ester ion (DCAE-). Another hand, as a ligand, $\mathrm{DCAE}^{-}$coordinates with copper atom to form polymer. No magnetic interactions between copper(II) centres is attributed to too far between two paramagnetic copper ions. In liquid, this copper complex can electrocatalyze $\mathrm{H}_{2}$ production both from acetic acid and aqueous buffer. Our ongoing efforts are focused on controlling the ligand and reaction conditions to give related polymers with novel physical and chemical properties.

\section{Acknowledgements}

This work was supported by the National Science Foundation of China (No. 20971045 and 21271073).

\section{References}

[1] W. Kaim, M. Moscherosch, Coord. Chem. Rev. 129 (1994) 157-193. 
[2] J. S. Miller, Angew. Chem. Int. Ed. 45 (2006) 2508-2525.

[3] J. D. Bagnato, W. W. Shum, M. Strohmeier, D. M. Grant, A. M. Arif, J. S. Miller, Angew. Chem. Int. Ed. 45 (2006) 5322-5326.

[4] L. Z. Tang, C. N. Lin, S. Z. Zhan, X. H. Xie, Inorg. Chem. Commun. 69 (2016) $16-19$.

[5] C. N. Lin, S. T. Ren, L. P. Ye, C. H. Chen, S. Z. Zhan, Inorg. Chem. Commun. 69 (2016) 24-27.

[6] F. A. Cotton, Y. Kim, J. Am. Chem. Soc. 115 (1993) 8511-8512.

[7] R. Gross, W. Kaim, Angew. Chem. Int. Ed. Engl. 26 (1987) 251-253.

[8] G. T. Yee, J. C. Calabrese, C. Vasquez, J. S. Miller, Inorg. Chem. 32 (1993) 377-378.

[9] W. Kaim, M. Moscherosch, Coord. Chem. Rev. 129 (1994) 157-193.

[10] G. Wang, H. Zhu, J. Fan, C. Slebodnick, G. T. Yee, Inorg. Chem. 45 (2006) 1406-1408.

[11] J. S. Miller, A. J. Epstein, Angew. Chem. Int. Ed. Engl. 33 (1994) 385-415.

[12] J. M. Manriquez, G. T. Yee, R. S. McLean, A. J. Epstein, J. S. Miller, Science 252 (1991) 1415-1417.

[13] G. T. Yee, J. M. Manriquez, D. A. Dixon, R. S. McLean, D. M. Groski, R. B. Flippen, K. S. Narayan, A. J. Epstein, J. S. Miller, Adv. Mater. 3 (1991) 309-311.

[14] J.-H. Her, P. W. Stephens, K. I. Pokhdnya, M. Bonner, J. S. Miller, Angew. Chem. Int. Ed. 46 (2007) 1521-1524.

[15] C. Kremer, C. Melián, J. Torres, M. P. Juanicó, C. Lamas, H. Pezaroglo, E. 
Manta, H. Schumann, J. Pickardt, F. Girgsdies, O. N. Ventura, F. Lloret, Inorg. Chim. Acta 314 (2001) 83-90.

[16] G. M. Sheldrick, SADABS, Program for Empirical Absorption Correction of Area Detector Data, University of Götingen, Götingen, Germany, 1996.

[17] G. M. Sheldrick, SHELXS 97, Program for Crystal Structure Refinement, University of Götingen, Götingen, Germany, 1997.

[18] F. Conan, B. L. Gall, J.-M. Kerbaol, S. L. Stang, J. Sala-Pala, Y. L. Mest, J. Bacsa, X. Ouyang, K. R. Dunbar, C. F. Campana, Inorg. Chem. 43 (2004) 3673-3681. [19] A. J. Fatiadi, Synthesis (1986) 249-284.

[20] Y. X. Zhang, L. Z. Fu, L. L. Zhou, S. Z. Zhan, W. Li, Synthetic Metals 212 (2016) 69-74.

[21] L. L. Zhou, T. Fang, J. P. Cao, Z. Zhu, X. Su, S. Z. Zhan, J. Power Sources 273 (2015) 298-304.

[22] H. I. Karunadasa, C. J. Chang, J. R. Long, Nature 464 (2010) 1329-1333.

[23] Q.-X. Peng, C.-N. Lin, Y.-X. Zhang, S.-Z. Zhan, C.-L. Ni. Z. Anorg. Allg. Chem. 642 (2016), 860-865.

[24] L. Tong, R. Zong, R. P. Thummel, J. Am. Chem. Soc. 136 (2014) 4881-4884.

[25] G. A. N. Felton, R. S. Glass, D. L. Lichtenberger, D. H. Evans, Inorg. Chem. 45 (2006) $9181-9184$.

[26] R. S. Nichloson, I. Shain, Anal. Chem. 36 (1964) 706-723.

[27] Y. Sun, J. P. Bigi, N. A. Piro, M. L. Tang, J. R. Long, C. J. Chang, J. Am. Chem. Soc. 133 (2011) 9212-9215. 
[28] T. Fang, W. Li, S.-Z. Zhan, X. Wei, J. Coord. Chem. 68 (2015) 573-585.

[29] T. Fang, L.-Z. Fu, L.-L. Zhou, S.-Z. Zhan, Electrochim. Acta 161 (2015) $388-394$. 

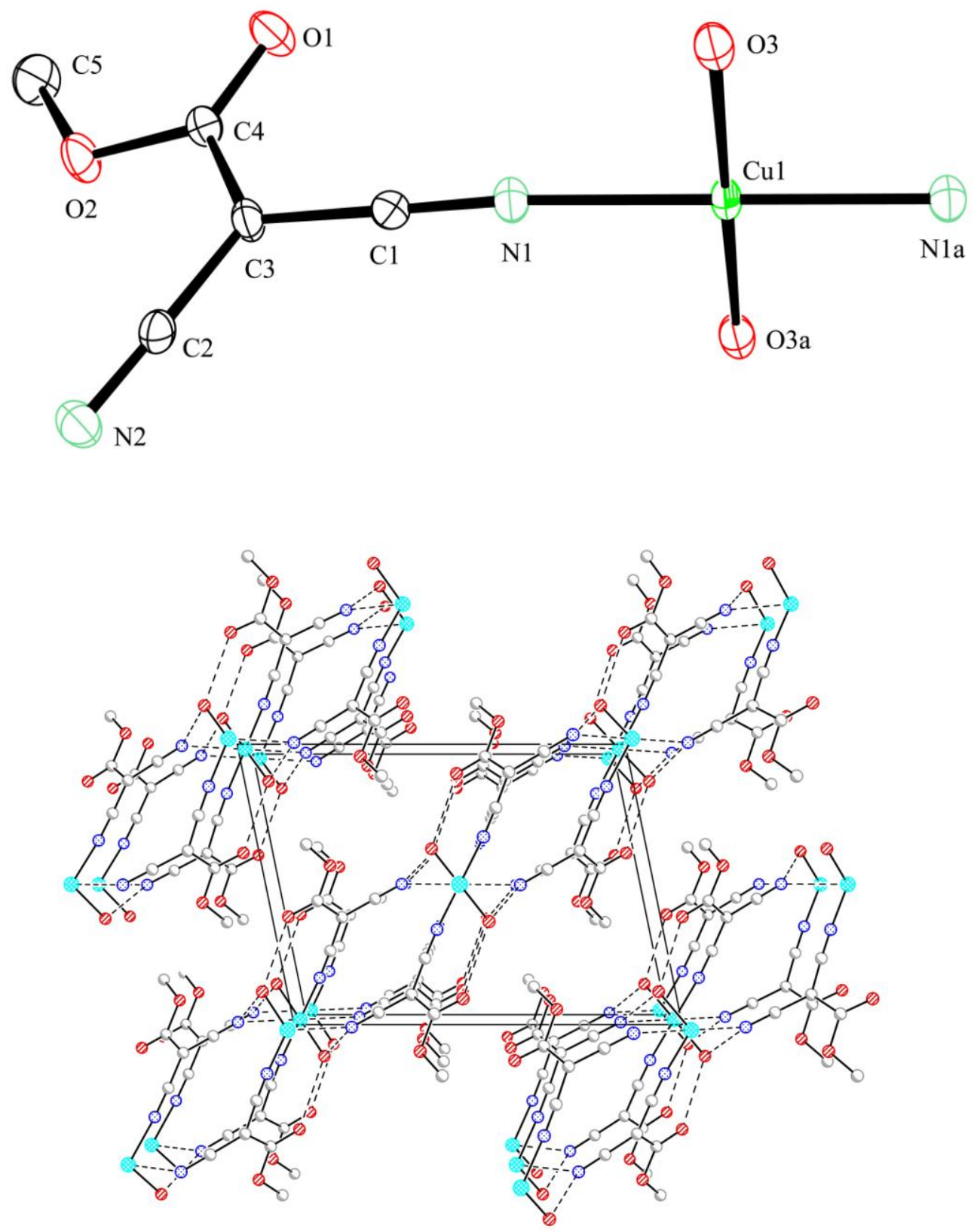

Fig. 1. ORTEP drawing of complex 1 with thermal ellipsoids on the 50\% probability level (hydrogen atoms are not shown) (top) and crystal packing diagram of complex $\mathbf{1}$ (down). 

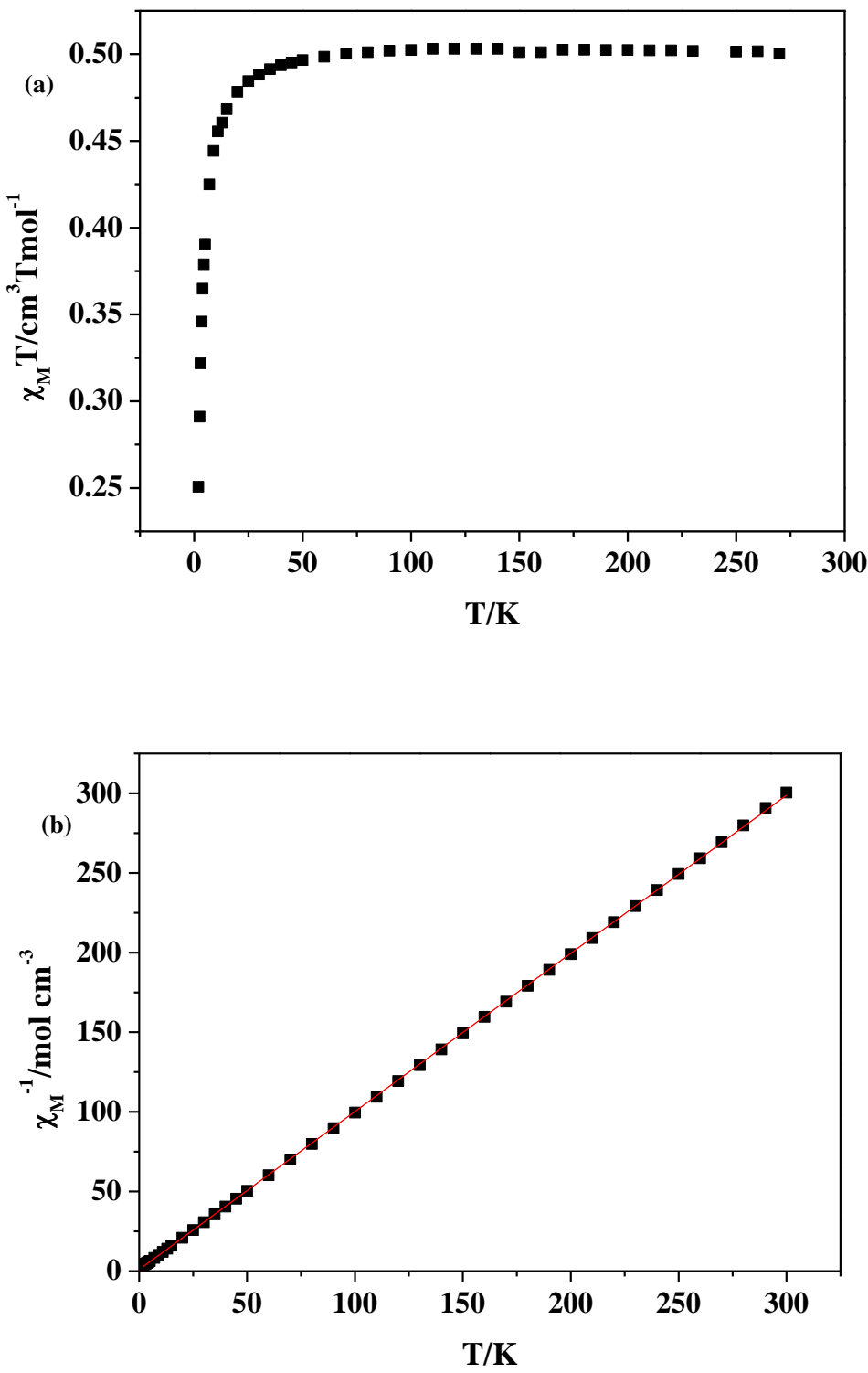

Fig. 2. (a) Temperature dependence of $\chi_{M} \mathrm{~T}$ at an applied field of 1000 Oe. (b) Temperature dependence of $\chi_{M}{ }^{-1}$ at an applied field of 1000 Oe. 


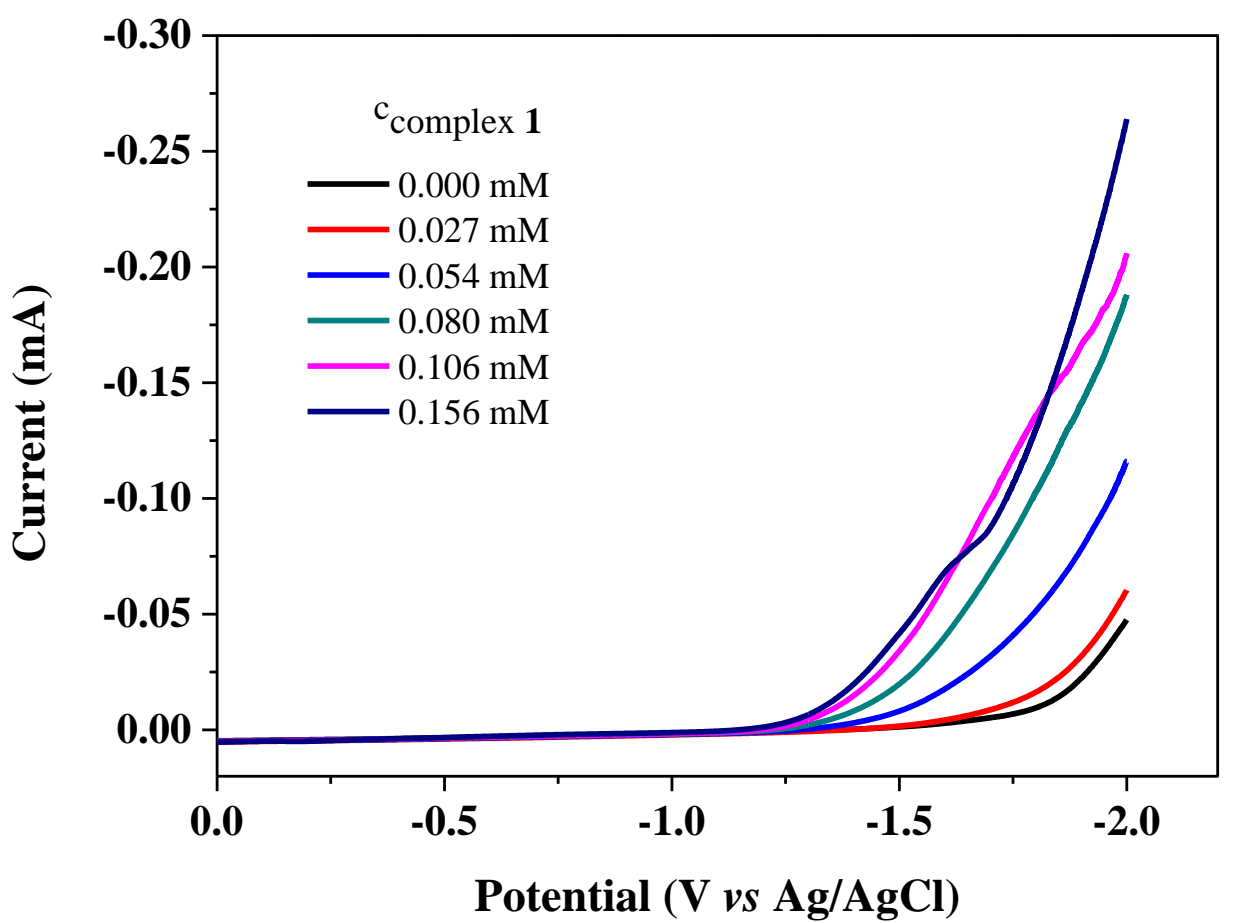

Fig. 3. Linear scan voltammetrys of neutral buffer solutions ( $\mathrm{pH} 7.0)$ without and with complex 1. Conditions: Glassy carbon working electrode, Pt counter electrode, $\mathrm{Ag} / \mathrm{AgCl}$ reference electrode, scan rate $100 \mathrm{mV} / \mathrm{s}$. 

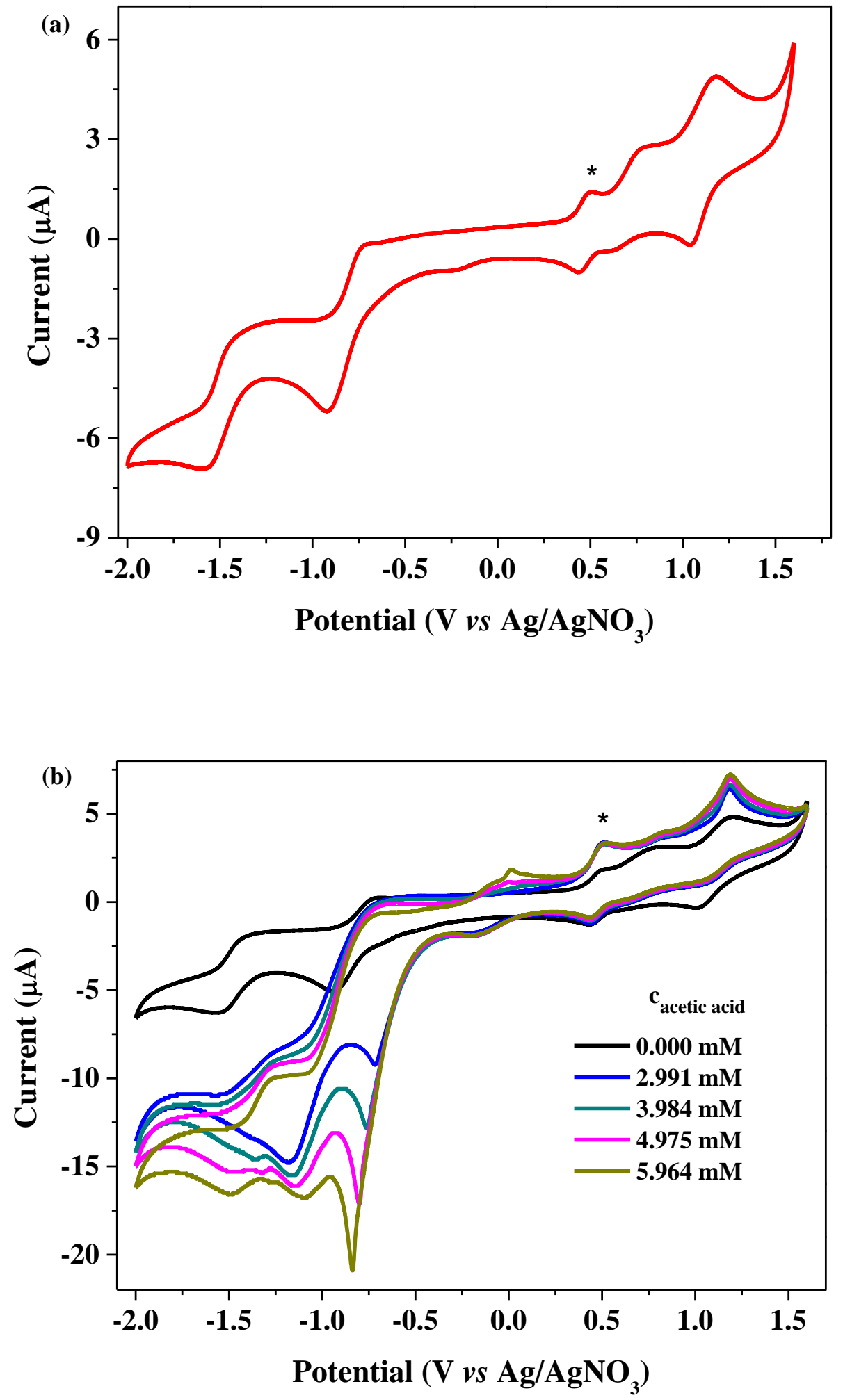

Fig. 4. (a) Cyclic voltammograms (CVs) of $2.67 \mathrm{mM}$ solution of complex 1 in $\mathrm{CH}_{3} \mathrm{CN}$ with $0.10 \mathrm{M}$ of $\left[\mathrm{n}-\mathrm{Bu}_{4} \mathrm{~N}\right] \mathrm{ClO}_{4}$ at a glassy carbon electrode and a scan rate of 
$100 \mathrm{mV} / \mathrm{s}$. Ferrocene internal standard (*). (b) CVs of a $2.67 \mathrm{mM}$ solution of complex 1, with varying concentrations of acetic acid in $\mathrm{CH}_{3} \mathrm{CN}$. Conditions: $0.10 \mathrm{M}$ $\left[\mathrm{n}-\mathrm{Bu}_{4} \mathrm{~N}\right] \mathrm{ClO}_{4}$ as supporting electrolyte, scan rate: $100 \mathrm{mV} / \mathrm{s}$, glassy carbon working electrode ( $1 \mathrm{~mm}$ diameter), $\mathrm{Pt}$ counter electrode, $\mathrm{Ag} / \mathrm{AgNO}_{3}$ reference electrode, $\mathrm{Fc}$ internal standard. 

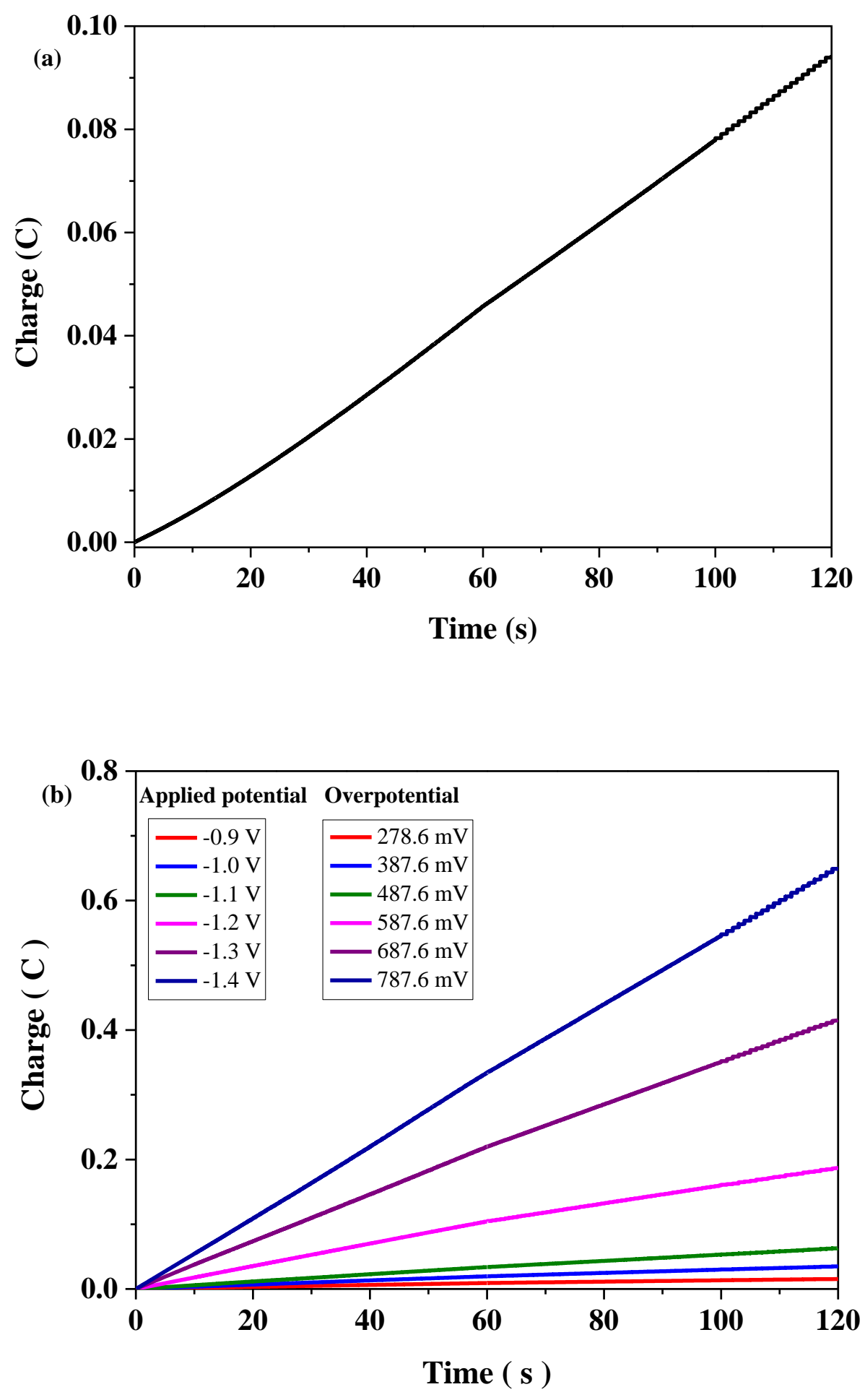

Fig. 5. (a) Charge buildup versus time from electrolysis of a $7.14 \mu \mathrm{M}$ complex 1 in a $0.25 \mathrm{M}$ buffer (pH 7.0). All data have been deducted blank. (b) Charge buildup versus time from electrolysis of a $0.25 \mathrm{M}$ buffer $(\mathrm{pH} 7.0)$ under $-1.45 \mathrm{~V}$ versus $\mathrm{Ag} / \mathrm{AgCl}$. Conditions: scan rate: $100 \mathrm{mV} / \mathrm{s}$, glassy carbon working electrode $(1 \mathrm{~mm}$ 
diameter), $\mathrm{Pt}$ counter electrode, $\mathrm{Ag} / \mathrm{AgCl}$ reference electrode. 